\title{
CSR Analysis: A Reflection from Businesses and the Public in Thailand
}

\author{
Nuntana Udomkit ${ }^{1}$ \\ ${ }^{1}$ Mahidol University International College, Mahidol University, Thailand \\ Correspondence: Nuntana Udomkit, Mahidol University International College, Mahidol University, Thailand. \\ E-mail: nuntana.udo@mahidol.ac.th
}

\author{
Received: January 17, 2013 Accepted: February 19, 2013 Online Published: March 20, 2013 \\ doi:10.5539/jms.v3n2p155 URL: http://dx.doi.org/10.5539/jms.v3n2p155
}

\begin{abstract}
Corporate Social Responsibility (CSR) Initiatives have grown dramatically worldwide, no exception in export-oriented country like Thailand. Business sector now engages in a vast number of CSR initiatives. However, there is a lack of empirical research pertaining to CSR, typically in developing countries, wherein there are often questions about understanding of CSR, level of engagement, and lack of consumers' support.

This research attempts to investigate CSR in Thai context and attempts to, firstly, examine CSR from the business point of view; why and how businesses, implement CSRs. Second, to investigate public's perception and expectation for the business to be "socially responsible", and their decisions to exercise their purchasing power over the companies with and without CSR initiatives. Third, to investigate how businesses and the public communicate and connect with each other with regards to CSR initiatives.

This research selected petroleum business as a focus of study. The combined qualitative and quantitative research methods were employed. The research conducted semi-structured interview with the management of PTT Group and Shell (Thailand) and conducted survey on consumers' side.

This research confirms the necessity for businesses to engage in CSR. With stronger public awareness on CSR, businesses can no longer move on without being socially responsible. Evidently, this research finds that public has higher expectation towards firms to be socially responsible. They are willing to exercise their power to support companies that are socially responsible and are able to use their sanction to boycott companies that do not act in a socially responsible manner, especially when those two products of the similar quality are sold at the same price. In view of CSR communications, it is found that CSR communications to publics do have a critical impact on perception toward businesses. The respondents have significantly improved their perceptions towards the companies once they learnt more about the good causes that the companies contributed to the society.
\end{abstract}

Keywords: corporate social responsibility, consumer behavior, CSR communications, petroleum, Thailand

\section{Introduction}

\subsection{Corporate Social Responsibility (CSR) - A Brief Review}

The philosophy of corporate social responsibility (CSR) is deemed to have its roots in ancient Greece and Rome whilst then kings, emperors, governors, senators, or prefects of those times drew up codes or rules of conducts. Nevertheless, things only started to take head for CSR when in the 1920s, during an address, Wallace B. Donham, Dean of Harvard Business School at that time, indicated that the "future of civilization" was also part responsibility of businesses. Then by the beginning of the welfare state in the 1930s, literature on CSR started to appear fueling debate about business and society. Incidentally, the term "corporate social responsibility" was not coined until 1953 by Howard Bowen in his book, "Social Responsibilities of the Businessman" (Bowen, 1953). Nevertheless, between the 1960s to the 1980s, further debates on CSR, particularly about the nature of responsibilities and who was/were to be responsible for society continued into the 1990s. It was also during those times, with the introduction of the work by Edward Freeman's 'Stakeholder Theory' in 1984, that CSR became a management practice. And ever since then till this day, CSR has grown to include environmental management, corporate social performance, stakeholder partnerships, poverty, and sustainability (Asongu, 2007; Blowfield and Murray, 2008; Brass Center, 2007). 
CSR has been viewed in a wide variety aspect by CSR scholars. Maignan and Ferrell (2004) systematically summarized the past conceptualizations of CSR into four categories. First, CSR is viewed as social obligation. This approach of CSR is influenced by Carroll (1979) by which social obligations are distinguished into (a) economic obligations (to be productive and economically viable), (b) legal and ethical obligations (adhere to the law and acknowledged social/cultural values and norms), and (c) philanthropic obligations (proactively giving back to society).

The next category viewed CSR as stakeholder obligation. This approach is influenced by Freeman (1984) in which views that business has obligations toward those who are directly or indirectly affected or are affected by the firm's internal and/or external activities such as: (a) organizational (e.g. employees, customers, shareholders, suppliers), (b) community (e.g. local residents, special interest groups), (c) regulatory (e.g. municipalities, regulatory systems), and (d) media stakeholders.

The third approach perceived CSR as ethics driven. That is, CSR accounts for a positive commitment to society. This approach provides normative criteria to evaluate the extent to which actual business practices can or cannot be considered as socially responsible (Jones 1995). Such ethics-driven assessment of CSR asserts the appropriateness of ethical policy on specific corporate activities independently of any social or stakeholder obligation (e.g. Donaldson and Preston 1995; Swanson 1995).

Lastly, CSR as thought to be managerial processes. This approach has depicted CSR in terms of concrete organizational processes and often analyzed under the label of corporate social responsiveness with focus more on a pragmatic or strategic view of CSR; that is - how can an individual firm successfully manage CSR? Or how can CSR generate organizational benefits? CSR is viewed as an essential part in corporate strategy (Elkington, 1998; Porter and Kramer, 2006; The Economist, 2005); wherein integrating public interest and concerns into business planning and decision making allows a firm to better upheld their standings in the marketplace.

To date, many CSR initiatives have been advocated by various organizations worldwide. Aspect for CSR initiatives to take root in business were highlighted in the International Business Report 2008 by Grant Thornton, which underscored seven main factors, from the corporate point of view, that seemingly contribute to the popular drive of corporate responsibility practices in businesses. The factors are; 1) the need for businesses to attract and retain high quality staff, 2) cost management, 3) establish confidence and loyalty among customers, 4) tax relief, 5) saving the planet, 6) building investor relations and 7) government pressures (Grant Thornton, 2008).

Through time, a number of researches on CSRs have produced evidences to support the notion that implementing CSR can bring benefits to businesses and hence can be used in an instrument to enhance their business performance such as:

- Consumers will willingly engage in positive word of mouth about firms committed to actions that demonstrated adherence to institutional norms and the law (Handelman and Arnold, 1999).

- $\quad$ Proven positive relationships between CSR initiatives and customer loyalty (Drumwright, 1994, 1996; Maignan and Hult, 1999; Ogilvy, 2006).

- Consumers' willingness to actively support companies committed to cause-related marketing, environmentally friendly practices, or ethical business dealings are greatly increased (Barone et al., 2000; Berger and Kanetkar, 1995; Bird and Hughes, 1997; Creyer and Ross, 1997; Mintel, 1999).

- Consumers will readily sanction socially irresponsible companies, for example, by boycotting their products and services. Consequently, such negative corporate impacts from issues valued by stakeholders may lead to decreased stakeholder resources (Garrett 1987; Sen et al, 2001; Strong, 1996).

- Socially responsible corporate behaviors may also lead to increased human resource as firms rated high on CSR are perceived as more attractive by job applicants (Luce et al, 2001; Maignan and Hult, 1999; Turban and Greening, 1996).

\subsection{CSRs in Thailand}

Over the past years, a number of scholars have attempted to investigate CSRs practices in Thailand but in-depth research on CSR in Thailand remains embryonic. In general, the consent among researchers in this particular area is the rising trend in CSR initiatives and awareness on CSR in Thailand (Chapple and Moon, 2005; Kenan Institute of Asia, 2007; Grand Thornton, 2008; 2010; Hirunpattarasilp and Udomkit, 2011; Prayukvong and Olsen, 2009).

Nonetheless, what are the key drivers for the growth of CSR in Thailand remains a puzzle. Some observed that Thailand, as an exporting country, faced pressure from international firms in western countries, where CSR has 
become widely adopted; as well as from multinational companies operating in Thailand that brought with them a CSR culture. This leads to a growing consciousness of the need for socially responsible behavior (Prayukvong and Olsen, 2009). While another believes CSR concepts is not so different in terms of voluntariness that is widely practiced in Thailand (Pornchokchai, 2009).

Interestingly, Grant Thornton's CSR survey for Thailand in 2010 stated the result of "less than satisfactory" with the country falling behind on several key CSR factors. It was reported that the key driver of Thai CSR is for the purpose of "tax relief". Many research point out key problematic areas in CSR development in Thailand that with different interpretations of CSR and its priorities, it causes CSR to be anything ranging from simply donation, legal compliance, or corporate governance (Kraisornsuthasinee and Swierczek, 2009; Wottrich and Sastararuji, 2007). Also there is a rising concern on the way companies conduct their CSR - whether they could be call CSR? One of the extreme examples raised in Bangkok Post is a lighter company launched their corporate social responsibility (CSR) event to hand out 1,000 free ashtrays to keep people from disposing of their cigarette butts on the ground. It was questioned if this CSR campaign sounds more like a campaign to promote smoking than an activity promoting CSR (Bangkok Post, 2010).

\section{Research Objectives}

This research attempts to investigate CSR in Thai context and attempts to, firstly, examine CSR from the business point of view; why and how businesses, implement CSRs. Second, to investigate public's perception and expectation toward businesses to conduct businesses in a socially responsible manner, and their decisions to exercise their purchasing power over the companies with and without CSR initiatives. Third, to investigate how businesses and the public communicate and connect with each other with regards to CSR initiatives.

\section{Research Methodology}

This research selected petroleum business as a focus of study. This is due to the fact that petroleum business has engraved high concern on potential impact on environmental degradation and carries high expectation from society to conduct businesses in a socially responsible manner. PTT Group and Shell (Thailand) were selected for a comparison purpose. PTT Group is the largest player in energy and petroleum business in Thailand, whereas Shell is a global group of energy and petrochemical companies with the headquarters are in Hague, the Netherlands. Shell (Thailand) has long been established in 1946. Shell (Thailand) has engaged in several development projects in Thailand. PTT Group and Shell (Thailand) both have strong brand reputation in Thailand and have long engaged in CSR initiatives in Thailand such as education, sport, culture and community development.

The combined qualitative and quantitative research methods were employed. The research conducted semi-structured interview with the companies CEOs and/or assigned management in charge of the corporate social responsibility programs of those companies. This was undertaken during April 2010. On consumers' side, survey method was employed. The first part of the questionnaire aimed to evaluate the general characteristics of demographic data. The second part of the questionnaire was developed with basis on the 7-point Likert Scale, ranging from strongly disagree to strongly agree, to examine consumers' perception on CSR, awareness on CSR initiatives, factors that may affect consumers' purchasing decisions and attitudes over their exercising of purchasing power influencing product and brand switching on a corporate CSR perspective. The result from rating 7-point scaled question is interpreted as:

Table 1. Degree scale

\begin{tabular}{lll}
\hline Score Range & & Meaning \\
\hline 1.00 & 1.40 & Strongly disagree/ strongly dissatisfied \\
1.41 & 2.80 & Highly disagree/ dissatisfied \\
2.81 & 4.20 & Somewhat agree/ satisfied \\
4.21 & 5.60 & Highly agree/ highly satisfied \\
5.61 & 7.00 & Strongly agree/ strongly satisfied \\
\hline
\end{tabular}

The convenience sampling method was deployed due to its simplicity, fast, and inexpensive. We applied the sampling calculation method suggested by Yamane (1967) inferring to the total population of more than 100,000 and confidence level at 95\%. 500 questionnaires were distributed, and 423 completed questionnaires were used in our analysis. Demographic data of respondents was illustrated in the following Table 2. 
Table 2. Respondents' demographic data

\begin{tabular}{|c|c|c|}
\hline & No. of Respondents & Percentage \\
\hline \multicolumn{3}{|l|}{ Gender } \\
\hline Female & 257 & $60.8 \%$ \\
\hline Male & 166 & $39.2 \%$ \\
\hline \multicolumn{3}{|l|}{ Age } \\
\hline Below 26 & 112 & 26.5 \\
\hline $26-35$ & 139 & 32.9 \\
\hline $36-45$ & 92 & 21.7 \\
\hline $46-55$ & 58 & 13.7 \\
\hline $56-65$ & 20 & 4.7 \\
\hline Above 65 & 2 & 0.5 \\
\hline \multicolumn{3}{|l|}{ Marital Status } \\
\hline Single & 276 & 65.6 \\
\hline Married & 139 & 33.0 \\
\hline Others & 6 & 1.4 \\
\hline \multicolumn{3}{|l|}{ Education } \\
\hline Lower than Bachelor & 50 & 11.9 \\
\hline Bachelor & 223 & 53.1 \\
\hline Master & 130 & 31.0 \\
\hline Ph.D. and above & 17 & 4.0 \\
\hline \multicolumn{3}{|l|}{ Knowledge on CSR } \\
\hline Yes & 354 & 85.5 \\
\hline No & 60 & 14.5 \\
\hline
\end{tabular}

\section{Data Analysis}

\subsection{What, Why, and How Businesses Conduct Their CSR?}

Through the interview, it was found that PTT Group and Shell (Thailand) have clear CSR and sustainability policies, and embedded such policies into day to day operations. The executives emphasized firms' obligation to operate its business in a responsible manner to fulfill stakeholders' expectation, and cannot ignore the importance of social responsibility.

PTT Group and Shell (Thailand) have stated similar responsibilities to their stakeholders. For PTT Group, key six pillars of responsibilities are placed in its mission statement. First, to the country. PTT Group ensures long-term energy security by providing sufficient high-quality energy supply at fair pricing. Second, to society and community. PTT Group commits to be a good corporate citizen by protecting environment and improving the quality of life for communities. Third, to the shareholders. PTT assures to conduct profitable business leading to sustainable growth while providing optimum returns. Fourth, to the customers. PTT ensures customer satisfaction by delivering world-class quality products and services at fair prices. Fifth, to the business partners. PTT conducts business with partners on fair basis, promoting synergy and coordination, creating capabilities and efficiency in long-term business partnership. Finally, to the employees. PTT commits to provide supporting capability building in professional conduct, ensuring employees' well-being on par with other leading companies.

Similarly, Shell's business practices conforms five areas of responsibility. First, to its shareholders. Shell has the responsibility to protect shareholders' investment, and provide a long-term return competitive with those of other leading companies in the industry. Second, to its customers. Shell is responsible to win and maintain customers by developing and providing products and services which offer value in terms of price, quality, safety and environmental impact. Third, to its employees. Shell respects the human rights of employees and to provide them with good and safe working conditions, and competitive terms and conditions of employment, equal opportunity to develop his or her skills and talents. Fourth, Shell seeks mutually beneficial relationships with contractors, suppliers and in joint ventures. And fifth, to society. Shell commits itself to conduct business as responsible corporate members of society, to comply with applicable laws and regulations, to support fundamental human rights in line with the legitimate role of business, and to give proper regard to health, safety, security and the environment. 
With regards to their sustainability initiatives, PTT Group and Shell (Thailand) have undertaken similar sustainability initiatives. For example, initiatives on database (carbon footprint) management, reduction of greenhouse gas emission from its activities and products, research and development of clean technologies to reduce greenhouse gas emission. Both companies also carry a wide range of community support on education, sport, art and culture, social and environment.

For Shell (Thailand), although the scale of operation in Thailand is not as big as PTT Group, Shell (Thailand) also carries out a wide number of CSR activities. For example, with regards to biofuel from palm oil, one of the Thai government initiatives to promote biodiesel, Shell assures that the palm oil is produced in a sustainable manner. That is to plant in areas not jeopardizing human food, not destroy natural forests, and ensure that throughout its supply chain, everyone complies its tasks in a sustainable way, starting from production till it reaches the hand of customer. Moreover, on education front, Shell (Thailand), more than 40 years, provides scholarship to many schools and universities. Last year Shell launched its 'Learning Room' to assist primary schools in rural areas that lack of teachers and educational tools and media. On sport, Shell organises Shell-Equal marathon. On "Education and Innovation", Shell (Thailand) offers a forum for students to invent and build energy saving vehicles.

Both companies believe that conducting businesses in a socially responsible manner would contribute to sustainable development and would lead the company to be more competitive and more profitable. Nowadays, under globalization world, firms cannot be "bad". Customers and react quickly to any misconduct of firms, especially big international firms. Knowledge of CSR has been widely spread through media, education, and even in the government policies, and voluntary code of conduct. The trend will be on the rising and will pressure, directly or indirectly, businesses embed CSR in to their business practice. Additionally, with the stronger public voices and the rising number of monitoring organsiations, watchdog and NGOs, that advocates their work towards CSRs promotion, business can no longer move on without being socially responsible. By being part of community would give the company to earn "a license to grow and operate".

\subsection{Expectations: Businesses Have to Be "Socially Responsible"}

This research has found that public does have a high level of expectations to the businesses that they have a hold a responsibility to community and society. It was found that the respondents strongly agree that that all companies, regardless of their operational size need to contribute to society and the environment that they are operating in (mean $=5.88, \mathrm{SD}=1.222$ ). Respondents strongly agree that larger companies (like MNCs) should contribute more to society more than compared to smaller companies (like SMEs) (mean $=5.62, \mathrm{SD}=1.407$ ). They also expected that companies making larger amounts of (financial) profit need to contribute more to society than compared to companies which had gained smaller amounts of (financial) profit (mean $=5.70, \mathrm{SD}=1.38$ ). And lastly, among all, respondents gave the highest score to support the principle that companies with operations that effects society and the environment negatively need to help society more than those companies whose operations do not $($ mean $=6.03, \mathrm{SD}=1.254)$.

Table 3. Public's expectations towards businesses to be "socially responsible"

\begin{tabular}{lll}
\hline To what extent do you agree with the following statements & Mean & SD \\
\hline $\begin{array}{l}\text { All companies, regardless of their operational size need to contribute to society and the } \\
\text { environment that they are operating in }\end{array}$ & 5.88 & 1.222 \\
$\begin{array}{l}\text { Larger companies (like } M N C s \text { ) should contribute more to society more than compared to } \\
\text { smaller companies (like SMEs) }\end{array}$ & 5.62 & 1.407 \\
$\begin{array}{l}\text { Companies making larger amounts of (financial) profit need to contribute more to society } \\
\text { than compared to companies which had gained smaller amounts of (financial) profit }\end{array}$ & 5.70 & 1.385 \\
$\begin{array}{l}\text { Companies with operations that effects society and the environment negatively need to help } \\
\text { society more than those companies whose operations do not }\end{array}$ & 6.03 & 1.254 \\
\hline
\end{tabular}

\subsection{Is CSRs an Important Factor Underpinning Consumers' Choice?}

Move on to factors that underpin consumers' choice of gas station, this research has found that consumers buy products based on attributes of products that have more directly benefits or have impacts on them rather than CSR. CSR alone is not enough to be a key drive for consumers' purchasing

The analysis showed that consumers chooses gas stations based on 1) convenience such as being close to home or work or being on your route (mean $=5.67, \mathrm{SD}=1.208$ ), 2) facilities such as bathrooms, minimarts, ATM, 
restaurant and coffee shop $($ mean $=5.34, \mathrm{SD}=1.401), 3$.confidence in product quality $($ mean $=5.33, \mathrm{SD}=1.158)$ 4) compay's good reputation and social contributions (mean $=4.95, \mathrm{SD}=1.345)$, 5) service $($ mean $=4.86, \mathrm{SD}=$ $1.087)$, and 6) promotions (mean $=4.59, \mathrm{SD}=1.087)$.

Of the total respondents of 423,78 respondents $(18.9 \%)$ stated that they preferred to use Shell petrol station, while 335 respondents $(81.1 \%)$ had the preference on PTT service station. However, after comparing mean of each factor between groups of customers who prefer Shell to customers who prefer PTT, it was found that Shell's customers concerned more on the confidence in product, then convenience, service, promotion, facilities, and company's good reputation and social contributions. PTT customers are concerned more on convenience, facilities, products, Company's good reputation and social contributions, service and promotion.

Of those six factors, four of which have highly significant level of different perception between customers of Shell and PTT. First is on "facilities" such as bathrooms, minimarts, ATM, restaurant and coffee shop. Second is on "company's good reputation and social contributions". Under these two categories, consumers' perception toward PTT is significant higher than Shell. However, for "confidence in product quality" and "promotions", respondents identified higher scored for Shell on both factor. On confidence in product quality and promotion, average score for Shell stood at $5.72(\mathrm{SD}=1.161)$, while PTT was scored $5.24(\mathrm{SD}=1.145)$. For promotion, average score for Shell was $4.90(\mathrm{SD}=1.59)$, while PTT's score was $4.51(\mathrm{SD}=1.350)$. The differences between the two factors between respondents who are customers of Shell and who are customers of PTT proved significant (P-Value $=0.001$ and 0.028 respectively).

Table 4. Factors underpinned consumers' choice of gas station

\begin{tabular}{|c|c|c|c|c|c|c|c|c|}
\hline Reasons & $\begin{array}{l}\text { Mean } \\
(\mathrm{n}=423)\end{array}$ & SD & $\begin{array}{l}\text { Shell Mean } \\
(\mathrm{n}=78)\end{array}$ & SD & $\begin{array}{l}\text { PTT Mean } \\
(\mathrm{n}=334)\end{array}$ & SD & $\mathrm{t}$-Value & P-Value \\
\hline $\begin{array}{l}\text { Confidence in the quality } \\
\text { of product }\end{array}$ & 5.33 & 1.158 & 5.72 & 1.161 & 5.24 & 1.145 & 3.335 & $.001^{*}$ \\
\hline Service & 4.86 & 1.087 & 4.99 & 1.153 & 4.82 & 1.070 & 1.214 & .225 \\
\hline Promotions & 4.59 & 1.400 & 4.90 & 1.594 & 4.51 & 1.350 & 2.205 & $.028^{*}$ \\
\hline $\begin{array}{l}\text { Convenience (such as } \\
\text { being close to home or } \\
\text { work or being on your } \\
\text { route) }\end{array}$ & 5.67 & 1.208 & 5.68 & 1.314 & 5.66 & 1.181 & .098 & .922 \\
\hline $\begin{array}{l}\text { Facilities (such as } \\
\text { bathrooms, minimarts, } \\
\text { ATM, restaurant and } \\
\text { coffee shop) }\end{array}$ & 5.34 & 1.401 & 4.40 & 1.462 & 5.56 & 1.288 & -6.990 & $.000^{*}$ \\
\hline $\begin{array}{l}\text { Company's } \\
\text { reputation and social } \\
\text { contributions }\end{array}$ & 4.95 & 1.345 & 4.27 & 1.373 & 5.09 & 1.293 & -4.959 & $.000^{*}$ \\
\hline
\end{tabular}

\subsection{Respondents' Buying Behavior with Regards to CSR and Quality and Price of the Products and Their} Decisions to Exercise Their Purchasing Power

When asked about their buying behavior with regards to CSR, quality and pricing of their products, the respondents highly agreed that they will make purchases from companies that focused more on employees, social well-being, and the environment (mean $=6.27, \mathrm{SD}=1.350$ ). The research further asked respondents different scenarios to examine their willingness to change products if respondents learnt that the products or services that they used or were using were sold by a company that did not care about well-being of society, and the environment. $71.7 \%$ of respondents would exercise their purchasing power by switching their purchases to other company brands that sells similar products with the same quality and pricing. However, if there were variations in quality and price between the two substituted products, respondents' reactions were varied (see Table 5). 
Table 5. Scenarios and respondents' decision to switch to other substituted products that were produced by a socially responsible company

\begin{tabular}{llll}
\hline \multirow{2}{*}{ Scenarios } & Decision & & \\
& Switch & Not sure & Not switch \\
\hline Sells products with the same quality and price & $302(71.7 \%)$ & $88(20.9 \%)$ & $31(7.4 \%)$ \\
Sells products with the same quality but higher price & $125(29.7 \%)$ & $234(55.6 \%)$ & $62(14.7 \%)$ \\
Sells products with higher quality and price & $200(47.5 \%)$ & $168(39.9 \%)$ & $53(12.6 \%)$ \\
Sells products with lower quality but higher price & $76(18.1 \%)$ & $108(25.8 \%)$ & $235(55.6 \%)$ \\
Sells products with lower quality but at same price & $70(16.7 \%)$ & $160(38.1 \%)$ & $190(45.2 \%)$ \\
\hline
\end{tabular}

\subsection{Is It Important to Communicate CSR Internally and Externally?}

From our interview, the executives of both companies emphasized role that CEOs and executives on CSR by "Leading by Doing". The management must have the beliefs and values in being socially responsible to lead others to follow, at least in their own company.

Each company placed less emphasis on its CSR communications to the public. CSR was viewed as a means to help society and people in the wider context, not to make profit. It was argued that it was not necessary to present CSR projects on television or media. The money rather should be used for CSR projects rather than on air time on television. Moreover, firms should not use CSR for the purpose of public relations. It would be more justified to spend the money on good cause rather than on advertising. For example, in case of Shell English Program, which used to be on air on television for many years. After the company carefully considered the fact that the cost of the air time was about half the budget, Shell decided to shift the budget of airtime for community bases' English Program.

This research tested the impact on CSR's communication on perceptions toward firm by firstly asked the respondents to score their perceptions towards the companies. After that, CSR activities of the companies were presented. Then the respondents were then asked to score their perceptions towards firms again.

The result critically proved that CSR communications is a crucial mean to strengthen positive perception of the companies. It was found that more than $95 \%$ of respondents stated that they feel better for the companies. The perceptions of the companies images have been improved significantly at the level of confidence at $95 \%$ $(\mathrm{P}$-Value $=0.000)$. The paired-samples test analysis showed that consumers have increased score on their perception towards Shell by $39.83 \%$, and PTT by $20.92 \%$.

Table 6. Perception towards companies after respondents learnt more about their CRS activities: "before" and "after" comparison

\begin{tabular}{|c|c|c|c|c|c|}
\hline \multirow{2}{*}{ Companies } & \multicolumn{2}{|c|}{ Consumers' Perception } & \multirow{2}{*}{ Difference } & \multirow{2}{*}{ t-Value } & \multirow{2}{*}{ P-Value ${ }^{*}$} \\
\hline & Before & After & & & \\
\hline Shell & 4.82 & 6.74 & $1.92(+39.83 \%)$ & -31.939 & $.000^{*}$ \\
\hline PTT & 5.64 & 6.82 & $1.18(+20.92 \%)$ & -22.789 & $.000^{*}$ \\
\hline
\end{tabular}

* Level of Significance 0.05

\section{Conclusion and Managerial Implications}

This research confirms the necessity for businesses to engage in CSR. With stronger public awareness on CSR, businesses can no longer move on without being socially responsible. Evidently, this research finds that public has high expectation towards firms to be socially responsible. They are willing to exercise their power to support companies that are socially responsible and are able to use their sanction to boycott companies that do not act in a socially responsible manner, especially when those two products of the similar quality are sold at the same price.

In view of CSR communications, although from the reflection of the businesses, it is argued that instead of using money for public relations and advertisement, company should rater utilize it for the CSR projects itself. This holds true. However, as the research finding suggest, CSR communications to publics do have a critical impact 
on perception toward businesses. The respondents have significantly improved their perceptions towards the companies once they learnt more about the good causes that the companies contributed to the society. Hence, it is undeniable that communications are crucial means to link companies to the society. Businesses should seriously extend their communications to the public through their possible means, which are not limited to traditional media such as television, newspapers, and radio. With the development in the new media, firms now have more options of economical and powerful media to connect to the public i.e. through companies' website, blog, social media, forwarded mail, and free magazine and newspaper.

\section{Limitations and Future Research}

This research has two main limitations. Firstly, on company selection, this research focused only on two petroleum companies. Secondly, consumer survey was conducted based on convenient sampling method. Therefore, this set of limited samples cannot be considered representative of the total industry and population of Thai consumers.

Evidently, with public's higher expectation towards firms to be socially responsible, this will demand that the CSR iceberg be moved up another notch with more interactions between business and society. CSRs in the future will have to take account of the community need in order to create a "sustainable" CSR to bring forth direct or "in demand" assistances to community. Future research could attempt to examine more on interaction between business and community, and channels of communications that they can communicate "inside out" and "outside in" on CSR initiatives that proactively engaged business and community together.

\section{Acknowledgements}

The authors gratefully acknowledge the generous support and research funding from Mahidol University International College, Mahidol University. Also, the authors would like to express utmost gratitude to executives of PTT Group and Shell (Thailand) to provide opportunities to interview. Their insights greatly contribute to the completion of this paper.

\section{References}

Asongu, J. J. (2007). Strategic Corporate Social Responsibility in Practice. Lawrenceville, GA: Greenview Publishing Co.

Bangkok Post. (2011). Conducting CSR in Very Wrong Ways (May, 13, 2011). Bangkok Post, Bangkok.

Barone, J. M., Miyazaki, D. A., \& Taylor, A. K. (2000). The influence of cause-related marketing on consumer choice: does one good turn deserve another? Journal of the Academy of Marketing Science, 28(2), 248-262. http://dx.doi.org/10.1177/0092070300282006

Berger, E, I., \& Kanetkar, V. (1995). Increasing environmental sensitivity via workplace experiments? Journal of Public Policy and Marketing, 14(2), 205-215.

Bird, K., \& Hughes, D. (1997). Ethical consumerism: the case of 'fairly-traded' coffee. Business Ethics, 6(3), 159-167. http://dx.doi.org/10.1111/1467-8608.00063

Blowfield, M., \& Murray, A. (2008). Corporate Responsibility: A Critical Introduction. Oxford University Press.

Bowen, H. R. (1953). Social Responsibilities of the Businessman. Harper and Row, New York.

Brass Center. (undated). History of Corporate Social Responsibility and Sustainability. Retrieved June 15, 2010, from http://www.brass.cf.ac.uk/uploads/History_L3.pdf

Carroll, A. B. (1979). A three-dimensional conceptual model of corporate performance. Academy of Management Review, 4(4), 497-505.

Chapple, W., \& Moon, J. (2005). Corporate Social Responsibility (CSR) in Asia: A Seven-Country Study of CSR Web Site Reporting. Business and Society, 44(4), 415-441. http://dx.doi.org/10.1177/0007650305281658

Creyer, H. E., \& Ross, W. T. (1997). The influence of firm behavior on purchase intentions: do consumers really care about business ethics. Journal of Consumer Marketing, 14(6), 421-432. http://dx.doi.org/10.1177/0007650305281658

Donaldson, T., \& Preston, E. L. (1995). The stakeholder theory of the corporation: concepts, evidence and implications. Academy of Management Review, 29(January), 65-91.

Drumwright, E. M. (1994). Socially responsible organizational buying: environmental concern as a noneconomic 
buying criterion. Journal of Marketing, 58(July), 1-19. http://dx.doi.org/10.2307/1252307

Drumwright, E. M. (1996). Company advertising with a social dimension: The role of noneconomic criteria. Journal of Marketing, 60, 71-87. http://dx.doi.org/10.2307/1251902

Elkington, J. (1998). Cannibals with Forks: The Triple Bottom Line of 21st Century Business. Gabriola Is., B.C., New Society Publishers.

Freeman, R. E. (1984). Strategic Management: A stakeholder approach. Boston: Pitman.

Garrett, E. D. (1987). The effectiveness of marketing policy boycotts: environmental opposition to marketing. Journal of Marketing, 51(April), 46-57. http://dx.doi.org/10.2307/1251128

Grant Thornton. (2008). Corporate Social Responsibility - a necessity, not a choice, for sustainable business. Retrieved May 14, 2010 from http://www.gti.org/Press-releases/IBR-CSR.asp

Grant Thornton. (2010). Focus on: Thailand. Bangkok: Grant Thornton.

Handelman, M. J., \& Arnold, A. S. (1999). The role of marketing actions with a social dimension: appeals to the institutional environment. Journal of Marketing, 63, July, 33-48. http://dx.doi.org/10.2307/1251774

Hirunpattanasilp, T., \& Udomkit, N. (2011). Factors effecting comsumers' purchasing decisions on CSR banking: A case of commercial bank in Thailand. Rangsit Journal of Arts and Sciences, 1(1), January-June 2011, 27-34.

Jones, T. M. (1995). Instrumental Stakeholder Theory: A Synthesis of Ethics and Economics? Academy of Management Review, 20(2), 404-437. http://dx.doi.org/10.5465/AMR.1995.9507312924

Kenan Institute Asia. (2007). Recent Developments in Corporate Social Responsibility in Thailand. The ADB Regional Conference: Enhancing Corporate Social Responsibility in Asia. Bangkok: Asian Development Bank.

Kraisornsuthasinee, S., \& Swierczek, F. W. (2009). Doing well by doing good in Thailand. Social Responsibility Journal, 5(4), 550-565. http://dx.doi.org/10.1108/17471110910995393

Luce, A. R., Barber, E. A., \& Hillman, J. A. (2001). Good deeds and misdeeds: a mediated model of the effect of corporate social performance on organizational attractiveness. Business \& Society, 40(4), 397-415. http://dx.doi.org/10.1177/000765030104000403

Maignan, I., \& Ferrell, O. C. (2004). Corporate social responsibility and marketing: an integrative framework. Journal of the Academy of Marketing Science, 32(1), 3-19. http://dx.doi.org/10.1177/0092070303258971

Maignan, I., \& Hult, G. T. (1999). Corporate citizenship: cultural antecedents and business benefits. Journal of the Academy of Marketing Science, 7(4), 455-469. http://dx.doi.org/10.1177/0092070399274005

Mintel. (1999). The green and ethical consumer. Retrieved May 14, 2010, from http://www.mintel.co.uk

Ogilvy. (2006). CSR and brand management: which role can CSR play in delivering your brand promise?

Pornchokchai, S. (2009, August 10). CSR and Thai Financial Institutions. Prachachart Newspaper, p. 30.

Porter, E., \& Kramer, R. (2006). Strategy and Society the Link Between Competitive Advantage and Corporate Social Responsibility. Harvard Business Review, 76-93.

Prayukvong, P., \& Olsen, M. (2009). Research on CSR Development in Thailand By The NETWORK of NGO and Business Partnerships for Sustainable Development (Thailand). Bangkok: UNDP.

Sen, S., Gtirhan-Canli, Z., \& Morwitz, V. (2001). Withholding consumption: a social dilemma perspective on consumer boycotts? Journal of Consumer Research, 28(December), 399-417. http://dx.doi.org/10.1086/323729

Strong, C. (1996). Features contributing to the growth of ethical consumerism - a preliminary investigation. Marketing Intelligence \& Planning, 14(5), 5-13. http://dx.doi.org/10.1108/02634509610127518

Swanson, D. L. (1995). Addressing a theoretical problem by reorienting the corporate social performance model. Academy of Management Review, 20(1), 43-64. http://dx.doi.org/10.2307/258886

The Economist (2005, January 20th). A survey of corporate social responsibility. Retrieved May 14, 2010, from http://www.economist.com/node/3555212

Turban, B. D., \& Greening, W. D. (1996). Corporate social performance and organizational attractiveness to prospective employees? Academy of Management Journal, 40(3), 658-672. 
http://dx.doi.org/10.2307/257057

Wottrich, V. H., \& Sastararuji, D. (2008). Exploring CSR in Sweden, Thailand and Brazil: Insights from the Construction Industry. Retrieved May 14, 2010, from Digitala Biblioteket: http://202.198.141.77/upload/soft/0-article/+00000001/084.pdf 